Military Technical College

Kobry El-Kobbah,

Cairo, Egypt

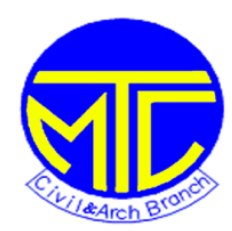

$11^{\text {th }}$ International Conference on Civil and Architecture Engineering

ICCAE-11-2016

\title{
Comparative Study for Sediment Yield from Air Born and Space Born
}

\author{
Gamal M. El Sheaky, Osama M. Moussa**, Ahmed M. El Desoky**, Hosam M El Hanafy** \\ *Civil Engineering Department, Ph D Candidate M T C. \\ ** M. T. C., Egypt
}

\begin{abstract}
Recently scientists acquire different Morphological data concerning large watersheds from air born as well as space born. The objective of this research is to compare the sediment that been yielded from Agora Watershed from the data acquired from different missions.

The study area is located on coastal shoreline of Egypt about $48 \mathrm{~km}$ east of Matrouh city. Morphological studies with the aid of photo- interpretation were carried out to determine the boundary of the watersheds from aerial photographs of scale 1:40000. Lengths of main channel and tributaries were measured by electronic planimeter (planix-5000). Slopes for main channel and tributaries were determined from photographic map of scale 1:25000.

Landsat image as one of space born mission with digital terrain model for the study area were used to determine land cover, watersheds boundaries and to measure the length and slopes of main channel and tributaries. Data acquired from morphological data , soil characteristics (geology, soil surface, particle size, soil erodibility factor, K) and rainfall for both air born and space born techniques were interested as an input data in WASHMO model in order to get water inflow and sediment discharge. Results were analyzed for each watershed and recommendations for previous work were stated.
\end{abstract}

Keyword: Watersheds, Hydrological model, sediment yield, Air born, Space born.

\section{Introduction}

Data extraction to monitor sediment that been yielded from watersheds is of vital concerns to scientists and hydrologists. Data collection from field required efforts, money and time to be done. These data are gives accurate results for detecting and monitoring the natural and morphological phenomena which effects land undulation and topographic Global change of the Earth's surface. 
During the last few decades' scientists thought strongly to acquire different data concerning large watersheds from air born as well as space born. The objective of this research is to compare the sediment that been yielded from Agora Watershed from the data acquired from different missions. Results were analyzed and recommendations for further work are included.

\section{Study Area}

The study area (Watershed) is located in the coastal region, about $48 \mathrm{~km}$ east of Matrouh city; it consists of Agoura Valley as main stream as well as few main channels runs in that watershed. This watershed covers an area of about $13 \mathrm{Km}^{2}$ and the outlet station of its three major sub-watersheds lies at a distance of about $700 \mathrm{~m}$. from the Southern boundary of Baghoush village. The watershed is characterized by light slope for a distance of $2250 \mathrm{~m}$. from the outlet station to reach a height of about $60 \mathrm{~m}$. above mean sea level (A.M.S.L.). It followed by steep slope to reach a height of $140 \mathrm{~m}$. A.M.S.L. at distance of $300 \mathrm{~m}$. from the end of the light slope.

\section{Geology and Soil Characteristics}

Sedimentary rocks are of common occurrence, accounting for approximately $75 \%$ of the earth's exposed land surface. Sedimentary rocks are formed from sediment deposits when lithification or consolidation of loose materials into solid rock occurs. The drying process associated with exposure creates joints or cracks which are perpendicular to the original bedding planes and have no lateral movement. There are two categories of sedimentary rock. The first category includes rocks that are clastic or fragmental, such as shales, sandstones, and conglomerates. The second category includes sedimentary rocks formed from those chemical and organic sediments precipitated from solution. Rocks formed from these sediments include limestones, gypsum and salt. Sandstone deposits are resistant to the forces of weathering. Joint patters, having the appearance of rectangular blocks, can be easily observed since there is little soil cover exists. The study area is considered as arid region. It is characterized by less than 20 inches of annual rainfall but sometimes it exceeds this value. In such arid region the land form are generally more rugged and without significant soil development over rock features.

\section{Model Description}

Watershed Storm Hydrograph-Multiple Option (WASHMO) model developed by Ward et al; 1979 consists of two models: one describing the hydrology of the watershed and the other describing the associated detachment and transport. The hydrology model mainly describes a design storm hydrograph. On the other hand, sediment yield in tons can be determined by using the modified version of the Universal Soil Loss Equation (USLE) developed by Hann and Barfield 1978 (Ward et al.;1979). 


\section{Data Acquisition}

Storms events characteristics with maximum rainfall amount and duration for the watershed which lies on the coastal region were acquired and studied to insert it in WASHMO model. Regarding to Meteorological rainfall data that have been recorded at Marsa Matruh station, by General Meteorological Authority, the maximum rainfall amounts during the period from 1978 until 1991 was found to be $103.5 \mathrm{~mm}$ at December, 13, 1990.

In this watershed, the lack of residual soil cover allows the joints in sand stone to have maximum control over the drainage pattern. Thus, it is usually an angular dendritic pattern, medium to course in texture as been interpreted from aerial photographs.

Land use for aerial photograph mission (1991) was interpreted and used with soil characteristics for the study area, collected from field investigation, laboratory analysis and sedimentary rock's topsoil characteristics given by Way (1978), to determine Soil Conservation Service - Curve Number (SCS-CN). SCS-CN represents the runoff potential of an area for the watershed, by using Hann and Barfield, 1978 approaches, see Tables 1 and 2, SCS-CN was found to be 79 .

Table 1: Definition of SCS hydrologic soil groups

\begin{tabular}{|c|l|}
\hline A & $\begin{array}{l}\text { These soils with a high infiltration rate. They are chiefly deep, well-drained } \\
\text { sands or gravels (Low runoff potential). }\end{array}$ \\
\hline B & $\begin{array}{l}\text { These soils with a moderate infiltration rate when thoroughly wet. They are } \\
\text { chiefly moderately deep, well drained soils of moderately fine to moderately } \\
\text { course texture. }\end{array}$ \\
\hline C & $\begin{array}{l}\text { These soils with a slow infiltration rate when wet. They are chiefly moderately } \\
\text { deep, well drained soils of moderately fine to moderately course texture. }\end{array}$ \\
\hline D & $\begin{array}{l}\text { These soils with a very slow infiltration rate. They are chiefly clay soils with a } \\
\text { high swelling potential, soils with a permanently high water table, soils with a } \\
\text { clay pan at or near the surface and shallow soils over nearly impervious } \\
\text { materials(High runoff potential). }\end{array}$ \\
\hline
\end{tabular}


Table 2: Runoff Curve Number for selected agriculture.

(Antecedent rainfall $=1.4-2.1$ inches $)$

\begin{tabular}{|c|c|c|c|c|c|}
\hline & \multirow[b]{2}{*}{ Land use description } & \multicolumn{4}{|c|}{ Hydrological soil group } \\
\hline & & A & $\mathrm{B}$ & $\mathrm{C}$ & $\mathrm{D}$ \\
\hline \multirow{2}{*}{$\begin{array}{c}\text { Cultivated } \\
\text { Land }\end{array}$} & Without conservation treatment & 72 & 81 & 88 & 91 \\
\hline & With conservation treatment & 62 & 71 & 78 & 81 \\
\hline \multirow{2}{*}{$\begin{array}{l}\text { Pasture or } \\
\text { range land }\end{array}$} & Poor condition & 68 & 79 & 86 & 89 \\
\hline & Good condition & 39 & 61 & 74 & 80 \\
\hline Meadow & Good condition & 30 & 58 & 71 & 78 \\
\hline \multirow{2}{*}{$\begin{array}{l}\text { Wood or } \\
\text { Forest land }\end{array}$} & Thin stand, poor cover, no mulch & 45 & 66 & 77 & 83 \\
\hline & Good cover & 25 & 55 & 70 & 77 \\
\hline
\end{tabular}

The value of soil erodibility factor( $\mathrm{K}$ ) is varied from a specific kind of soil to another according to the different properties of soil itself. Silt fraction content, percent of sand in soil, soil structure, organic matter content and permeability class are the most common properties that have been used to determine such factor either from empirical equations, tables or from soil erodibility nomographs. From nomograph, K was determined and found to be 0.14 (Wischmeier and Smith,1978).

Morphological studies with the aid of photo- interpretation were carried out to determine the boundary of the watersheds from aerial photographs of scale 1:40000. Lengths of main channel and tributaries were measured by electronic planimeter (planix-5000) as shown in Figure 1.

A 90 m resolution of Digital Elevation Model (DEM) provided by Shuttle Radar Topography Mission (STRM) for the study area is used to describe the elevation of the Agora watershed. Main stream and tributaries were extracted from DEM by using Watershed Modeling System (WMS) software. Agora watershed was determined from both DEM and the drainage pattern for this catchment is shown in Figure 2. 


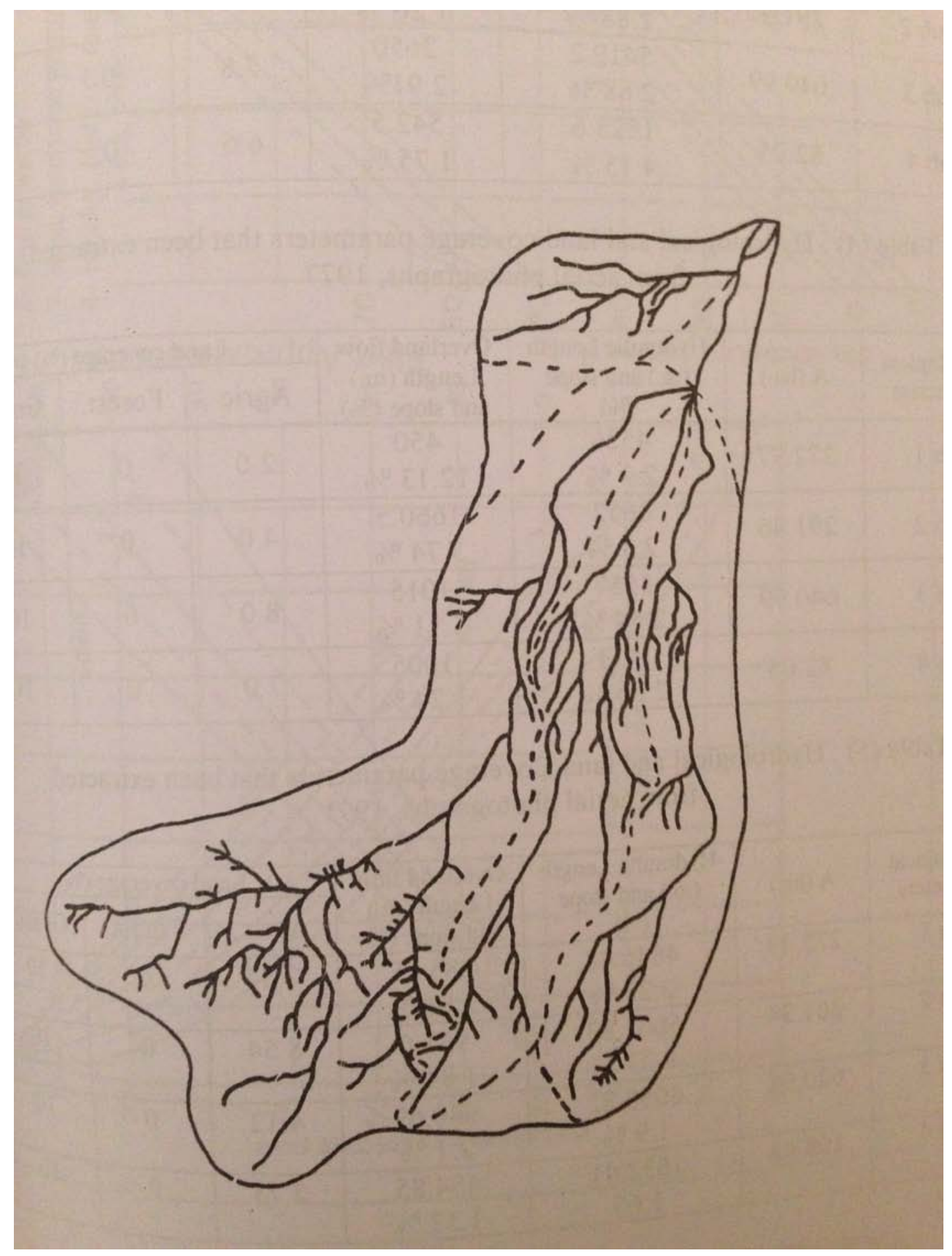

Figure (1) : Drainage Pattern of the Agora Watershed interpreted from Air Born At 1991 (Scale 1:40000)

Source : Moussa, et al.,1999. 


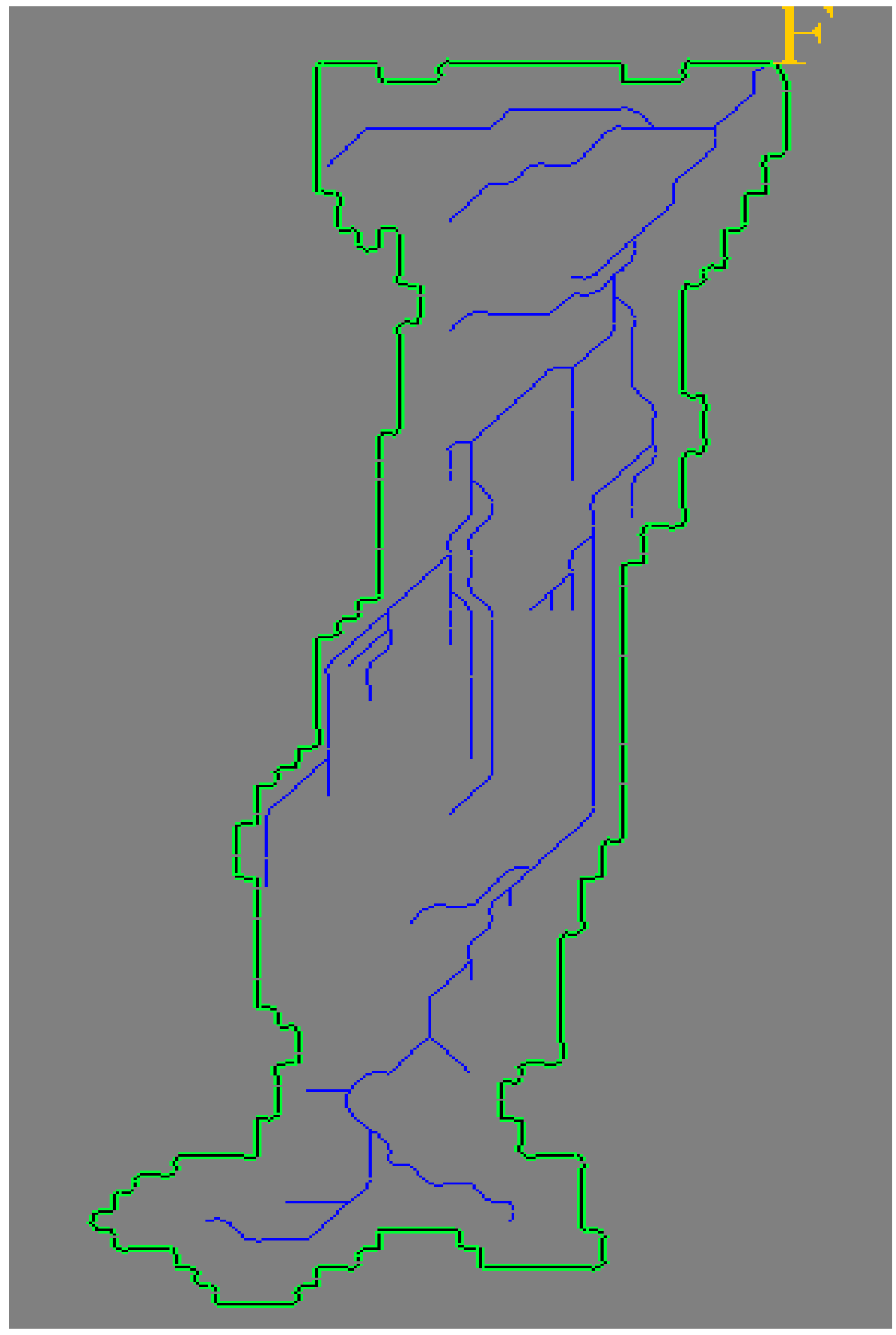

Figure (2) : Drainage Pattern of the Agora Watershed interpreted from Space Born 


\section{Data Input in WASHMO}

Hydrological and land coverage parameters that been extracted from aerial photograph (1991) were tabulated in Table 3.

Table 3: Hydrological and land coverage parameters that been extracted from aerial photograph, 1991.

\begin{tabular}{|c|c|c|c|c|c|c|c|}
\hline \multirow{2}{*}{$\begin{array}{l}\text { Hydrological } \\
\text { parameters }\end{array}$} & \multirow[t]{2}{*}{ A ( ha ) } & \multirow{2}{*}{$\begin{array}{l}\text { Hydraulic } \\
\text { length(m) } \\
\text { \&Slope\% }\end{array}$} & \multirow{2}{*}{$\begin{array}{l}\text { Channel } \\
\text { length } \\
\text { from } \\
\text { outlet St. }\end{array}$} & \multirow{2}{*}{$\begin{array}{l}\text { Overland } \\
\text { flow } \\
\text { length \& } \\
\text { Slope\% }\end{array}$} & \multicolumn{3}{|c|}{ Land Coverage } \\
\hline & & & & & Agric. & Forest & Grass \\
\hline Sub-1 & 272.43 & $\begin{array}{c}4846.48 \\
2.23 \%\end{array}$ & 1250 & $\begin{array}{l}885.05 \\
2.86 \%\end{array}$ & 2.84 & 0 & 0.10 \\
\hline Sub-2 & 261.34 & $\begin{array}{c}5061.83 \\
2.23 \%\end{array}$ & 1250 & $\begin{array}{l}921.60 \\
1.84 \%\end{array}$ & 8.54 & 0 & 0.10 \\
\hline Sub-3 & 620.93 & $\begin{array}{c}6050.82 \\
1.9 \%\end{array}$ & 1250 & $\begin{array}{l}940.69 \\
2.1 \%\end{array}$ & 4.12 & 0 & 0.10 \\
\hline Sub-4 & 108.43 & $\begin{array}{c}1632.41 \\
1.65\end{array}$ & 0 & $\begin{array}{l}484.85 \\
1.32 \%\end{array}$ & 2.73 & 0 & 0.10 \\
\hline
\end{tabular}

Global parameters and the other input parameters for the watershed which extracted from Digital Elevation Model were inserted as follows:

\section{GLOBAL PARAMETERS}

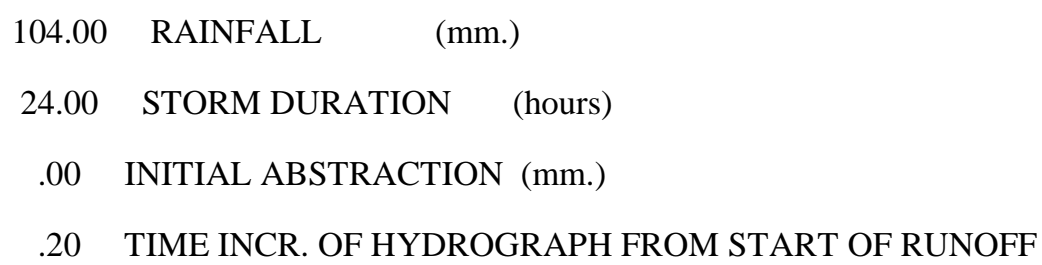

2 RAINFALL DISTRIBUTION : SCS TYPE 2 CURVE

1 = THE NUMBER OF WATERSHEDS 


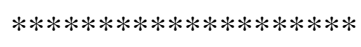

\section{RAINFALL PARAMETERS}

79.00 SCS CURVE NUMBER

1 UNIT HYDROGRAPH : DOUBLE TRIANGLE

\section{MAP PARAMETERS}

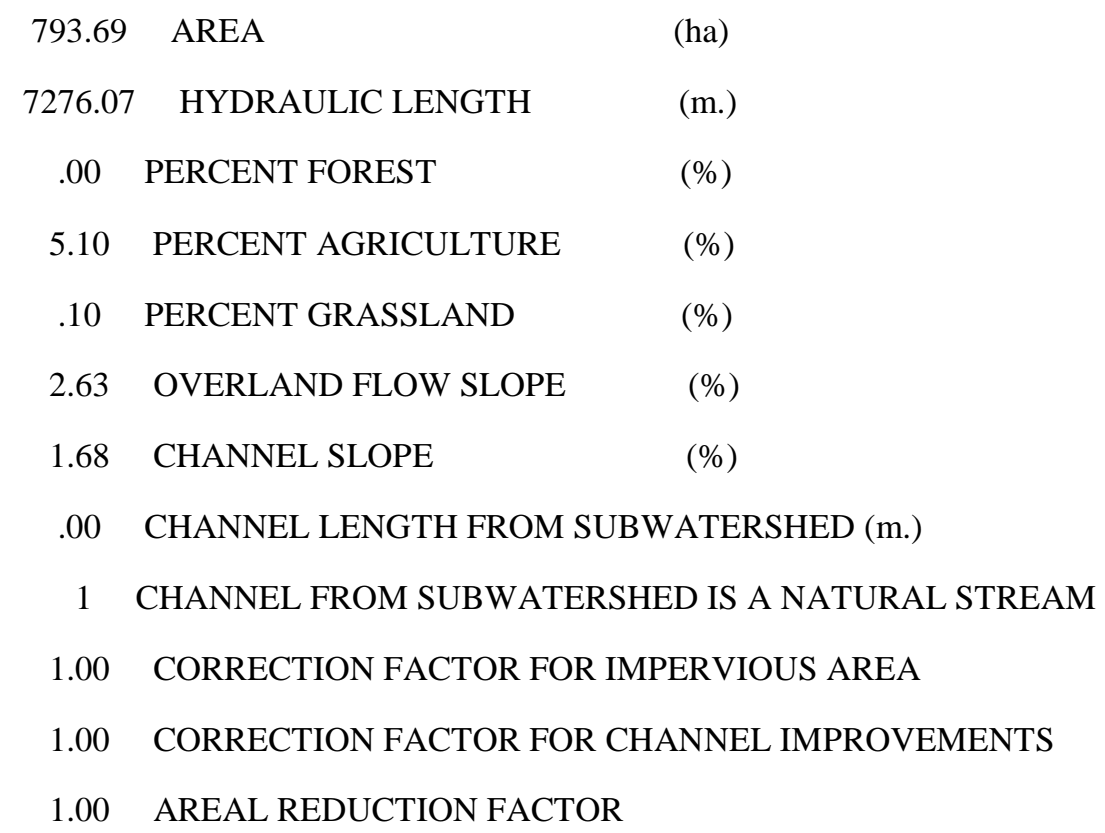

\section{SEDIMENT PARAMETERS}

1 SWITCH FOR SEDIMENT DATA

.14 SOIL ERODIBILITY PARAMETER K

452.37 OVERLAND FLOW LENTH (in $\mathrm{m}$.)

.10 COVER OR CONSERVATION PRACTICE FACTOR

2.65 SPECIFIC GRAVITY OF THE SEDIMENT PARTICLES

2.00 EXPONENT OF THE FLOW SEDIMENT LOAD RELATIONSHIP

PARTICLE SIZE DISTRIBUTION OF SEDIMENT FLOW 


$\begin{array}{cc}\text { PART. SIZE } & \% \text { FINER } \\ \text { mm. } & \% \\ ----------------- \\ .060 & .0 \\ .200 & 20.0 \\ .600 & 82.0 \\ 2.000 & 100.0\end{array}$

\section{Results and analysis}

Results of storm sediment graph for watershed Agora by using aerial photograph at 1991 and by the aid of Digital Elevation Model (DEM) provided by Shuttle Radar Topography Mission (STRM) were tabulated in Table 4.

Table 4: storm sediment graph for watershed Agora

\begin{tabular}{|l|c|c|}
\hline \multicolumn{1}{|c|}{ Sediment Phenomena } & $\begin{array}{c}\text { From Air- } \\
\text { Born }\end{array}$ & $\begin{array}{c}\text { From Space- } \\
\text { Born }\end{array}$ \\
\hline Total sediment yield (tons) & 1493.36 & 892.00 \\
\hline Peak sediment concentration (mg/l) & 8.41 & 3.79 \\
\hline Time to peak sediment concentration (hours) & 12.40 & 13.40 \\
\hline
\end{tabular}

\section{Conclusion and recommendations}

The resulted sediments yielded from Agora Watershed by using Air born and Space born missions are completely differ. The reason of that can be concluded as follows:

1) Main stream and tributaries were interpreted from Air born, aerial photograph, taken at 1991.

2) Main stream and tributaries were extracted from DEM (2003) by using Watershed Modeling System (WMS) software.

- It is recommended to use DEM for the same year as aerial photograph was taken and with resolution of $30 \mathrm{~m}$ instead of $90 \mathrm{~m}$. 


\section{References}

- Ward, A.D., Hann, C.T. and Tapp, J.S. ,1979, “ The DEPOSITS Sedimentation Pond Design Manual “, Institute for mining and minerals Research Office of Informational Services, University of Kentucky, Lexington, Kentucky.

- Hann, C.T. and Barfield, B.J., 1978. Hydrology and Sedimentology of Surface Mined Lands. Office of Continuing Education and Extension College of Engineering. University of Kentucky, Lexington, Kentucky.

- Way, D.S., 1978. Terrain Analysis Community Development Series, Second Edition, Dowden, Hutchinson \& Ross, Inc. Stroudsburg, Pennsylvania, McGRaw-Hill Book Company, New York.438p.

- Wishmeier W.H. and Smith, D.D. 1978, “ Predicting rainfall Erosion Losses” , A guide to conservation planning. Science and Education Administration, United States Department of Agriculture Hyattsville, Maryland, pp58.

- $\quad$ Moussa, O.M., Abdelmetaal, N.H., Elmongy, A. E. and Mohamed, H. E.,1999 Effect of Environmental Changes on Drainage Pattern and Urban Planning along Coastal Regions, ICCAE-3, Military Technical College, Cairo, Egypt. 